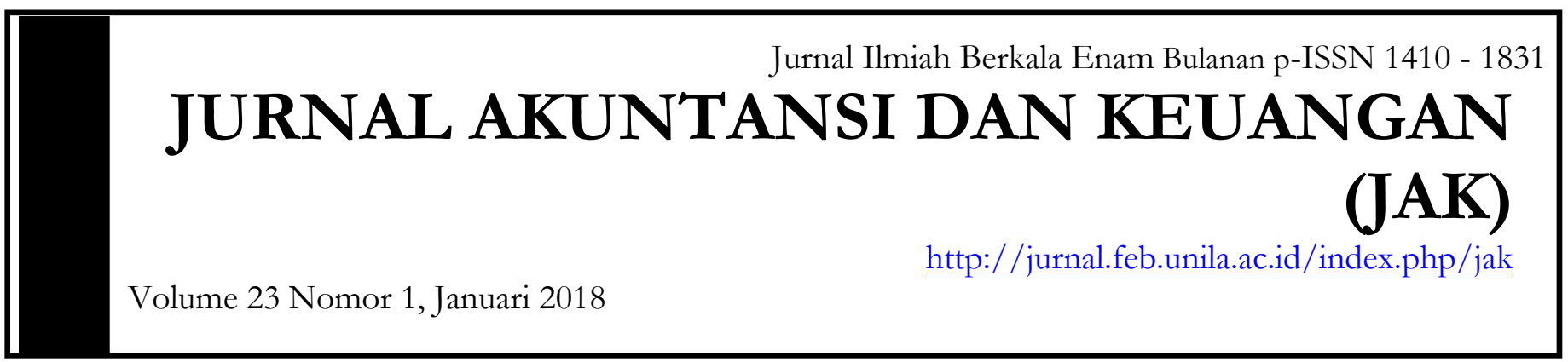

\title{
AGENCY COST INFLUENCE TOWARD DIVIDENDS POLICY AT MANUFACTURING COMPANY LISTED IN IDX
}

\author{
Liya Ermawati ${ }^{1}$, Harsono Edwin Puspita ${ }^{2}$ \\ ${ }^{1}$ Program Studi Akuntansi FEB Universitas Lampung \\ ${ }^{2}$ Program Studi Akuntansi FEB Universitas Lampung
}

\section{InformasiNaskah}

Update Naskah:

Dikumpulkan: 19 Sept

2017;

Diterima: 22 January 2018;

Terbit/Dicetak: 30 January

2018.

\section{Keywords:}

Dispertion of Ownership, Managerial Ownership, Collateral Assets, Debt Policy, Dividens Policy

\begin{abstract}
Agency intereralation is a manager (agent) that is controlled by others with a contract of one or more shareholder. Manager has their own interest in decision making, but they also have a responsibality to maximize shareholder's welfare. This conflict of interest always becomes a problem, that is agency problem. To solve this problem, will need some cost, namely agency cost that is related to dividens policy. The interelation between agency and shareholder is a new development to minimize agency cost. The research aims to prove the influence of agency cost towards dividends policy empirically. Dimention used to measure the agency cost is dispertion of ownership, managerial ownership, collateral assets, and debt policy, while dividens policy by dividen payout ratio. Sampling methode applied is purposive sampling, with financial report and company annual report as secondary data used. Sample used in this research is 27 manufacturing companies listed in Indonesia Stock Exchange (IDX) from 20102012. Analyzing method used is multiple regression through SPSS ver.16. the outcome of this research is dispertion of ownership, managerial ownership, collateral assets, and debt policy significantly influence in dividens policy partially.
\end{abstract}




\section{A. PENDAhULUAN}

Dalam perusahaan sering sekali tejadi konflik kepentingan yang ditunjukkan dalam hal perbedaan kepentingan antara manajer (agent) dan pemegang saham. Perbedaan kepentingan ini dapat terjadi akibat perbedaan pandangan manajer dan pemegang saham dalam melakukan investasi mengenai keputusan pendanaan terhadap suatu proyek yang akan dipilih perusahaan. Pertentangan ini dapat muncul kemungkinan yang disebabkan manajer menginvestasikan dana yang tidak memiliki prospek yang baik ke depannya ataupun penggunaan dana yang berdasarkan pandangan pemegang saham sebagai suatu pemborosan semata ataupun menguntungkan salah satu pihak yang memungkinkan tidak optimalnya return yang akan diterima pemegang saham atas tindakan yang dilakukan manajer tersebut. Perbedaan kepentingan tersebut yang memicu permasalahan keagenan antara manajer (agent) dan pemegang saham.Menurut Husnan dan Pudjiastuti (2006) masalah keagenan (agency problems) muncul dalam dua bentuk, yaitu antara pemilik perusahaan (principals) dengan pihak manajemen (agent).

Potensi masalah keagenan dapat terjadi pada perusahaan apabila kepemilikan saham yang dimiliki oleh para pemegang saham persentasenya kecil, hal yang demikian membuat kontrol para pemegang saham akan semakin berkurang terhadap manajer.Hal tersebut membuat para manajer akan mengabaikan tujuan memaksimalkan kekayaan pemegang saham, sehingga hal ini akan menimbulkan konflik antara manajer dan pemilik (pemegang saham).dan masalah keagenan dapat juga muncul karena apabila kepemilikan saham terlalu menyebar, sehingga kontrol yang dilakukan oleh pemegang saham terhadap manajer akan semakin berkurang pula.

Masalah konflik kepentingan terjadi juga antara pemegang saham dengan pihak manajemen, kepemilikan saham manajerial adalah keadaan dimana manajer memiliki saham dalam perusahaan atau manajer tersebut sekaligus sebagai pemegang saham perusahaan. Menurut Wahyudi dan Baidori (2008) kepemilikan manajerial yang besar akan menurunkan biaya keagenan karena ada rasa kepemilikan pada diri manajerial sehingga mereka bertindak sesuai dengan kepentingan pemegang saham, yang mengakibatkan perusahaan membayar deviden lebih rendah kepada pemegang saham. Kepemilikan manajerial adalah keadaan dimana manajer memiliki saham dalam perusahaan atau manajer tersebut sekaligus sebagai pemegang saham perusahaan.Hal ini ditunjukkan dengan besarnya persentase kepemilikan saham oleh pihak manajemen perusahaan. Manajer yang memiliki saham perusahaan tentunya akan menselaraskan kepentingannya sebagai manajer dengan kepentingannya sebagai pemegang saham. Kesetaraan tersebut semakin membuat manajer bertanggungjawab atas apa yang dilakukannya bagi perusahaan karena mereka akan memperoleh dampak sebagai pemegang saham. Menurut Wahyudi dan Baidori (2008) kepemilikan manajerial yang besar akan menurunkan biaya keagenan karena ada rasa kepemilikan pada diri insider sehingga mereka bertindak sesuai dengan kepentingan pemegang saham, yang mengakibatkan perusahaan membayar dividen lebih rendah kepada pemegang saham sedangkan semakin rendah insider ownership akan meningkatkan biaya keagenan sehingga sebagai konsekuensinya perusahaan membayar dividen lebih tinggi kepada pemegang saham.

Kebijakan deviden telah lama menjadi isu menarik dalam literature keuangan.Hasil penelitian sebelumnya tentang pengaruh biaya agensi yang terdiri dari variable penyebaran kepemilikan saham, kepemilikan saham, aktiva yang dijaminkan dan kebijakan hutang terhadap kebijakan deviden menunjukkan hasil yang tidak konsisten. Oleh karena itu, penelitian ini dilakukan untuk mereplikasi penelitian-penelitian sebelumnya. Berdasarkan latar belakang diatas maka dapat di rumuskan masalah sebagai berikut :"apakah biaya agensi berpengaruh terhadap kebijakan deviden pada perusahaan manufaktur yang terdaftar di Bursa Efek Indonesia”. Penelitian ini bertujuan untuk membuktikan secara empiris pengaruh biaya agensi terhadap kebijakan deviden pada perusahaan manufaktur yang terdaftar di Bursa Efek Indonesia. 


\section{B. LANDASAN TEORI DAN PENGEMBANGAN HIPOTESIS Hubungan Keagenan}

Menurut Jensen dan Meckling (1976) hubungan keagenan merupakan suatu kontrak dimana satu atau lebih orang memerintah orang lain untuk melakukan suatu jasa atas nama principal serta wewenang kepada agent untuk membuat suatu keputusan yang terbaik bagi principal. Jika kedua belah pihak tersebut mempunyai tujuan yang sama untuk memaksimumkan nilai perusahaan, maka di yakini akan bertindak dengan cara yang sesuai dengan kepentingan principal.

Adapun faktor- faktor yang mendorong timbulnya biaya agensi adalah sebagai berikut :

1. Penyebaran kepemilikan saham

Penyebaran kepemilikan saham adalah jumlah penyebaran kepemilikan saham dari seluruh saham yang beredar dari suatu perusahaan .penyebaran kepemilikan saham di percaya mampu mempengaruhi jalannya perusahaan yang pada akhirnya akan mempengaruhi kinerja . masalah keagenan terjadi apabila kepemilikan saham menyebar sehingga pemegang saham secara individual tidak dapat mengendalikan manajemen.

\section{Kepemilikan manajerial}

Kepemilikan manajerial merupakan bagian dari struktur kepemilikan perusahaan yang terkait dengan corporate governance.Nuraeni (2010) Kepemilikan manajerial didefinisikan sebagai kepemilikan saham perusahaan oleh dewan direksi dan komisaris perusahaan. Besarnya kepemilikan saham yang dimiliki oleh direksi dan komisaris perusahaan menunjukkan seberapa besar insentif bagi direksi dan komisaris dalam mensejajarkan kepentingan mereka dengan kepentingan para pemegang saham. Nur'aeni (2010) mengartikan kepemilikan saham manajerial adalah proporsi saham biasa yang dimiliki oleh para manajemen, yang dapat diukur dari presentase saham biasa yang dimiliki oleh pihak manajemen yang secara aktif terlibat dalam pengambilan keputusan perusahaan.

\section{Aktiva yang dapat dijaminkan}

Aktiva yang dapat dijaminkan merupakan besarnya aktiva yang di jaminkan kepada kreditor untuk menjaminkan pinjamannya. Menurut Husnan dan Pudjiastuti (2006) apabila jaminan yang diberikan mempunyai harga pasar yang jelas dan mudah dijual, maka kredit yang diberikan dapat mencapai proporsi yang cukup besar. Sebaliknya apabila jaminan tersebut merupakan aktiva yang sangat spesifik dan sangat susah menjualnya maka kreditor mungkin hanya akan memberikan kredit dengan proporsi relative rendah.

\section{Kebijakan hutang}

Keputusan pendanaan berkaitan dengan pemilihan sumber dana baik yang berasal dari dalam maupun dari luar perusahaan sangat mempengaruhi nilai perusahaan. Sumber dana perusahaan dari internal berasal dari laba ditahan.

\section{METODE PENELITIAN}

\section{Objek penelitian}

Objek penelitian dalam penelitian ini adalah perusahaan manufaktur yang terdaftar di Bursa Efek Indonesia (BEI) dari laporan keungan tahunan 2010 sampai dengan tahun 2012.

\section{Variabel penelitian}

Variabel dependen penelitian ini adalah kebijakan deviden yang diproksikan dengan dividend payout ratio (DPR), sedangkan variable independen dalam penelitian ini adalah biaya agensi yang diproksikan dengan penyebaran kepemilikan saham, kepemilikan manajerial, aktiva yang dapat dijaminkan, dan kebijakan hutang.

\section{Definisi operasional variable}

Variabel dependen dalam penelitian ini adalah kebijakan dividen.Kebijakan deviden di proksikan dengan dividend payout ratio (DPR).dividend payout ratio adalah rasio antara deviden per share 
terhadap earning per share.

Dividend payout ratio $=$ dividend per share

Earning per share

Sedangkan variabel independen dalam penelitian ini adalah biaya agensi. Biaya agensi yang diteliti yaitu :

1. Penyebaran kepemilikan saham

Dispertion of ownership di hitung dengan menggunakan rumus variance, karena besarnya nilai variance menunjukkan bahwa data kepemilikan saham semakin terkonsentrasi pada satu atau beberapa pemegang saham.Variance merupakan suatu ukuran dari sebaran disekitar rata-rata hitung. Menurut Zubir (2011) variance dispertion of ownership di hitung dengan :

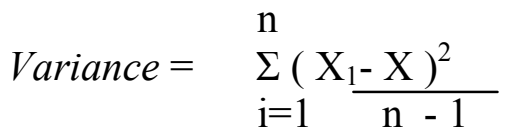

Keterangan :

$\mathrm{X} 1$ : persentase kepemilikan saham satu kelompok

$\mathrm{X}$ : rata-rata kepemilikan saham

$\mathrm{N}$ : jumlah data

2. Kepemilikan Manajerial

Menurut Mollah et al. (2000) kepemilikan manajerial adalah persentase kepemilikan saham oleh manajemen dalam suatu perusahaan. Kepemilikan manajerial adalah persentase kepemilikan saham oleh pihak manjemen yang secara aktif ikut dalam pengambilan keputusan perusahaan. Dengan adanya kepemilikan manajerial dan mensejajarkan kepentingan antara manjemen dan pemegang saham, sehingga manajer akan merasakan kerugian apabila keputusan yang diambil salah.

Kepemilikan manajerial = Jumlah Saham Pihak Manajemen

3. Aktiva yang dijaminkan

Total Saham Beredar

Aktiva yangdapat dijaminkan (collateral), merupakan perbandingan antara aktiva tetap bersih dengan total aktiva. Aktiva yang dijaminkan adalah dana yang diinvestasikan oleh perusahaan dalam pendirian badan usaha yang di maksudkan untuk membiayai kegiatan.usaha di samping memenuhi peraturan yang di tetapkan, Mollah (2002)

Collateral asset:Total aktiva tetap - penyusutan

Total aktiva

\section{4. $\quad$ Kebijakan hutang (Debt to equity ratio )}

Keputusan pendanaan berkaitan dengan pemilihan sumber dana baik yang berasal dari dalam maupun dari luar perusahaan sangat mempengaruhi nilai perusahaan. Sumber dana perusahaan dari internal berasal dari laba ditahan dan depresiasi, sedangkan sumber dana eksternal perusahaan berasal dari para kreditur yang merupakan hutang bagi perusahaan, dan dana yang diperoleh dari pemilik perusahaan murpakan modal sendiri. Kebijakan hutang menggambarkan kemampuan perusahaan dalam membayar hutang dengan modal yang dimilikinya. Menurut Harahap (2009) debt equity ratio dihitung dengan :

DER : Total hutang

Modal

Tabel 1 Tuliskan judulnya di bagian atas tanpa tanda titik

\begin{tabular}{|c|c|c|c|}
\hline No. & Uraian & Jumlah & Keterangan \\
\hline
\end{tabular}


pembuatan table

Ukuran Font untuk isi tabel diperbolehkan lebih kecil 1-2 dari TNR 12

Sumber: Tuliskan sumbernya menggunakan tanda titik.

\section{ANALISIS DAN PEMBAHASAN}

\section{Hasil Pengujian Hipotesis}

\section{Uji f dan uji T}

Pengujian uji f untuk memperoleh kepastian bahwa model yang dihasilkan secara umum dapat digunakan maka diperlukan suatu pengujian secara bersama-sama.Gujarati dalam Ghozali (2006).

Dengan taraf nyata dan signifikansi a $=0,05$ dengan asumsi:

Jika $\mathrm{F}$ hitung $<\mathrm{F}$ table artinya tidak ada pengaruh (ditolak)

Jika F hitung $>\mathrm{F}$ table artinya ada pengaruh (diterima)

Pengujian dilakukan denganmenggunakan uji Tsignificance $0,05(\alpha=5 \%)$ yang digunakan untuk menguji hasil dari analisis korelasi yang didapat secara kebetulan.Gujarati dalam Ghozali (2006). Dengan taraf nyata dan signifikansi a $=0,05$ dengan asumsi :

Jika $\mathrm{T}$ hitung $<\mathrm{T}$ table artinya tidak ada pengaruh (ditolak)

Jika $\mathrm{T}$ hitung $>\mathrm{T}$ table artinya ada pengaruh (diterima).

\section{Regresi Linear Berganda}

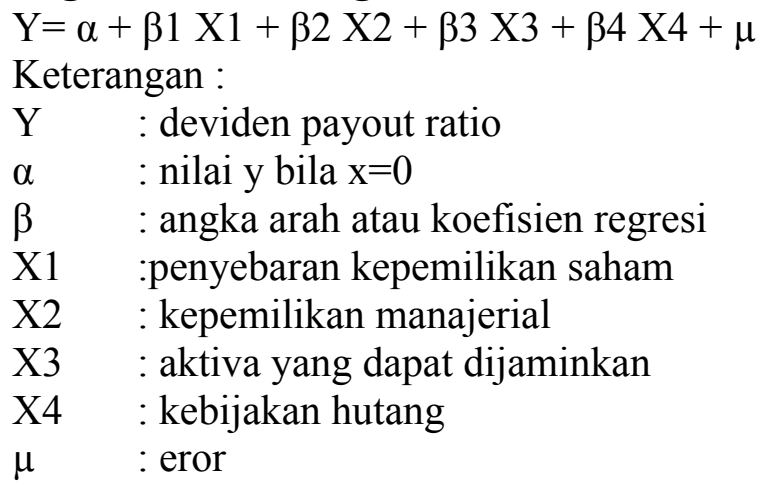

\section{Hasil Uji Hipotesis 1}

Pengujian hipotesis 1 , nilai t hitung sebesar 3,519<2,000 dengan tingkat signifikansi sebesar 0,001 $<0,05$. Dengan demikian Ha ditolak yang berarti, Penyebaran kepemilikan saham berpengaruh signifikan terhadap kebijakan dividen.

\section{Hasil Uji Hipotesis 2}

Pengujian hipotesis 2 , nilai t hitung sebesar 9,663<2,000 dengan tingkat signifikansi sebesar $0,000>0,05$. Dengan demikian Ha ditolak yang berarti, kepemilikan manajerial berpengaruh signifikan terhadap Kebijakan Dividen.

\section{Hasil uji Hipotesis 3}

Pengujianhipotesis 3 , nilai t hitung sebesar $-3.350<2,000$ dengan tingkat signifikansi sebesar $0,001>0,05$. Dengan demikian Ha ditolak yang berarti, aktiva yang dijaminkan berpengaruh signifikan terhadap Kebijakan Dividen.

\section{Hasil Uji Hipotesis 4}


Pengujian hipotesis 4 , nilai t hitung sebesar $-2.713<2,000$ dengan tingkat signifikansi sebesar $0,008>0,05$. Dengan demikian Ha ditolak yang berarti, kebijakan hutang berpengaruh signifikan terhadap Kebijakan Dividen.

Persamaan hasil regresi linear berganda adalah :

$\mathrm{Y}=23,101+0.005 \mathrm{X} 1+0,619 \mathrm{X} 2-0.172 \mathrm{X} 3-0.100 \mathrm{X} 4+2.886$.

Konstanta sebesar 23,101 artinya jika penyebaran kepemilikan saham, kepemilikan manajerial, aktiva yang dijaminkan, dan kebijakan hutang nilainya 0 maka kebijakan deviden nilainya 23,169. Koefisien regresi penyebaran kepemilikan 0,005 artinya jika penyebaran kepemilikan saham mengalami kenaikan satu satuan maka kebijakan deviden akan mengalami peningkatan 0,005 satuan dengan asumsi variable independen lainnya bernilai tetap.Koefesien kepemilikan saham 0.619 artinya jika kepemilikan manajerial mengalami kenaikan satu satuan maka kebijakan deviden akan mengalami peningkatan 0,619 satuan dengan asumsi variable independen lainnya bernilai tetap. Koefisien regresi aktiva yang dijaminkan $-0,172$ artinya jika aktiva yang dijaminkan mengalami peningkatan satu satuan maka kebijakan devidenakan mengalami penurunan -0.172 satuan dengan asumsi variable independen lainnya bernilai tetap. Koefisien regresi kebijakan hutang -0.100 artinya jika kebijakan hutang mengalami peningkatan satu satuan maka kebijakan deviden akan mengalami penurunan $-0,101$ satuan dengan asumsi variable independen lainnya bernilai tetap.

\section{Pembahasan}

Hasil uji hipotesis ke-1 membuktikan bahwa dari hipotesis alternatif (Ha) diterima.Penyebaran kepemilikan saham di percaya mampu mempengaruhi jalannya perusahaan yang pada akhirnya akan mempengaruhi kinerja.Kepemilikansaham yang menyebar dapat dijadikan alat sebagai monitoring oleh para pemegang saham untuk mengawasi setiap aktivitas manajemen.Hal ini akan mengurangi konflik keagenan. Bahwa ketika jumlah pemegang saham bertambah, maka para pemegang saham akan lebih mudah untuk mengontrol aktifitas manajer tersebut, sehingga pembayaran deviden yang harapkan juga akan sesuai dengan keinginan para pemegang saham. Salah satu cara untuk mengurangi masalah agensi karena menyebarnya kepemilikan perusahaan ialah dengan melakukan pembayaran dividen.

Hasil uji hipotesis ke-2 membuktikan bahwa dari hipotesis alternatif (Ha)diterima.Dengan Kepemilikan Manajerial yang tinggi mengindikasikan manajemen akan secara aktif ikut serta dalam setiap pengambilan keputusan. Semakin besar kepemilikan manajerial didalam perusahaan maka semakin produktif tindakan manajer dalam memaksimalkan laba.

Hasil uji hipotesis ke-3 membuktikan bahwa dari hipotesis alternatif (Ha)diterima. Artinya aktiva yang dapat dijaminkan berpengaruh signifikan terhadap kebijakan deviden, hasil penelitian menemukan bahwa penjaminan aktiva memiliki arah negative dengan kebijakan deviden, yang artinya semakin besar penjaminan Aktiva tetap,maka semakin besar keuntungan (laba) perusahaan yang akan dicadangkan untuk membayar hutang yang semakin besar, sehingga semakin kecil laba perusahaan yang dibagikan sebagai deviden.

Hasil uji hipotesis ke-4 membuktikan bahwa dari hipotesis alternatif (Ha)diterima.Kebijakan hutang berpengaruh negative bahwasanya semakin tinggi utang perusahaan maka perusahaan akan membayar dividen rendah karenaperusahaan cenderung menahan laba yang diperoleh sebagai Cadangan untuk melunasi kewajibannya.

\section{E. SIMPULAN DAN SARAN}

\section{Simpulan}

Berdasarkan hasil penelitian dan pembahasan yang telah dilakukan dapat disimpulkan:Hasil penelitian membuktikan bahwa Penyebaran Kepemilikan berpengaruh signifikan terhadap Kebijakan 
Dividen. Penyebaran kepemilikan saham di percaya mampu mempengaruhi jalannya perusahaan yang pada akhirnya akan mempengaruhi kinerja. Penyebaran Kepemilikansaham yang menyebar dapat dijadikan sebagai alat monitoring oleh para pemegang saham untuk mengawasi setiap aktivitas manajemen.

Hasil penelitian membuktikan bahwa Kepemilikan Manajerial berpengaruh signifikan terhadap Kebijakan Dividen. Walaupun kepemilikan manajerial

tinggi tidak mengindikasikan pembayaran dividen yang rendah karena di satu pihak terdapat sekelompok pemegang saham yang menginginkan suatu pembayaran dividen yang tinggi sebagai suatu penghasilan pada saat ini dibanding dengan sebagian kelompok pemegang saham lain yang mungkin lebih senang jika perusahaan menahan laba.

Hasil penelitian membuktikan bahwa Aktiva yang dapat dijaminkan berpengaruh signifikan terhadap Kebijakan Dividen. Aktiva yang dijaminkan merupakan jaminan bagi kreditur untuk memberikan pinjaman kepada perusahaan.

Hasil penelitian membuktikan bahwa Kebijakan Hutang (Debt to Equity Ratio) berpengaruh signifikan negative terhadap Kebijakan Dividen.

\section{Saran}

Peneliti selanjutnya diharapkan dapat menggunakan sampel yang lebih banyak dan tidak hanya perusahaan manufaktur saja melainkan dapat menggunakan sampel semua jenis perusahaan yang listing di Bursa Efek Indonesia.

Dalam penelitian ini, nilai $R$ square sebesar $64,7 \%$, artinya kebijakan deviden dapat dijelaskan oleh penyebaran kepemilikan saham, kepemilikan manajerial, aktiva yang dijaminkan dan kebijakan hutang sebesar $64,7 \%$, sehingga diharapkan peneliti selanjutnya lebih berhati-hati dalam pemilihan variable penelitian.

\section{REFERENSI}

Ang, J, Cole, R dan Lin, J. 1999. Agency Cost and Ownership Structure. Journalof Finance. Vol. 55: Hal. 81-106

Arikunto, Suharsimi. 2009. Manajemen penelitian. Penerbit PT rineka cipta, Jakarta

Asyik.2006. Dampak Pernyataan dan Nilai Wajar Opsi Pada Pengaruh Magnituda Kompensasi Program Opsi Saham Karyawan Terhadap Pengelolaan Laba. Simposium Nasional Akuntansi IX, Padang, 23-26 Agustus 2006.

Baridwan, Zaki. 2004. Intermediate Accounting. Penerbit BPFE, Yogyakarta.

Brigham, Eugene dan Joel F. Houston. 2006. Dasar- Dasar Manajemen Keuangan Jilid 1. Edisi Kesepuluh. Jakarta: Salemba Empat

Dempseys dan Caberg (1992:317) pengaruh agency cost dan terhadap deviden payout ratio variable yang digunakan adalah insider, grow1, grow 2, beta, stock (jumlah pemegang saham) dan deviden payout rasio.

Djarwanto subagio dan pangestu 1996.Analisis metodologi penelitian.Jakarta salemba empat.

Djumahir. 2009. Pengaruh Biaya Agensi, Tahap Daur Hidup Perusahaan, Dan Regulasi TerhadapKebijakan Dividen Pada Perusahaan Manufaktur Di Bursa Efek Indonesia. Jurnal Manajemen dan Kewirusahaan, VoL.11, No. 2, September 2009: 144-153. 
Eisenhardt, kath leem.M (1989). Agency theory : an assessment and review academy of management review, 14. 57-74.

Fauz dan Rosyidi. 2007. Pengaruh Aliran Kas Bebas, Kepemilikan Manajerial, Kepemilikan Institusional, Kebijakan Hutang, dan Collateral Asset terhadap Kebijakan Dividen. Jurnal Ekonomi dan Manajemen Volume 8, Nomor 2, Juni 2007.

F. Brigham, Eugene dan F. Houston, Joel. 2009. Dasar-Dasar Mananjemen Keuangan. Penerbit Salemba Empat, Jakarta 2010.

Ghozali, Imam. 2009. Aplikasi Analisis Multivariate Dengan Program SPSS. Badan Penerbit Universitas Diponegoro, Semarang.

Gujarati, Damodar N. 2007. Dasar-dasarEkonometrika. Jakarta: Erlangga.

Handoko 2002.Pengaruh struktur kepemilikan saham, aktiva yang dijaminkan,kebijakan hutang terhadap kebijakan deviden. Jakarta.

Harahap, Sofyan Syafri. 2009. Analisis Kritis atas Laporan Keuangan.Jakarta : Rajawali Pers, 2009

Hasan, Iqbal. 2004. Analisis data penelitian dengan statistic. Penerbit bumi aksara, Jakarta.

Husnan dan Pudjiastuti. 2006. Dasar-Dasar Manajemen Keuangan. Penerbit UPP STIM YKPN, Yogyakarta.

Ismiyanti, Fitri dan Hanafi, M Mamduh. Kepemilikan Manajerial, Kepemilikan Institusional, Risiko, Kebijakan Utang Dan Kebijakan Dividen. Analisis Persamaan Simultan. Simposium Nasional Akuntansi VI, Surabaya, 16-17 Oktober 2003.

Jensen, M.C. dan Meckling, W.H. 1976.Theory of Firm: Managerial Behaviour, Agency Cost and Ownership Structure.Journal of Financial Economics, (3): 305-360.

Kartika 2005.Analisis pengaruh kebijakan hutang terhadap nilai perusahaan. Jakarta.

Masdupi, Erni. 2005. "Analisis dampak struktur kepemilikan pada kebijakan hutang dalam mengontrol konflik keagenan". Jurnal Ekonomi dan Bisnis Indonesia Vol. 20, No.1, 2005, 57 59.

Meisser, W.F. 2008. "Auditing and Assurance Service - A Systematic Approach". 5 ${ }^{\text {th }}$ Edition. International Edition MCGraw-Hill Higher Education.

Mollah, Sabur, Kevin Keasay, and Helen Short. 2002. The Influence Of Agency costs on Dividend Policy in an Emerging Market. Working Papers.LeedsUniversity Business School.Western Campus.University of Leeds. LeedsL92 9JT. Uk.

Nur'aeni, Dini. 2010. Pengaruh Struktur Kepemilikan Saham Terhadap Kinerja Perusahaan. Universitas Diponegoro. Semarang.

Nurlaelah, dan Rasul, Abdul.2010. Praktikum Stastitika Ekonomi dan Bisnis.Jakarta : Mitra Wacana Media.

Putra I Nyoman Nugraha Ardana.2006. Analisis Biaya Keagenan Terhadap Kebijakan Dividen Pada Perusahaan Manufaktur Yang Terdaftar Di Bursa Efek Jakarta.Vol. 5, No. 2, Desember 2006. 
Putri, Imanda Firmantyas dan Mohammad Nasir.2006. Analisis Persamaan Simultan Kepemilikan Manajerial, Kepemilikan Institutional, Risiko, Kebijakan Hutang dan Kebijakan Dividen Dalam Perspektif Teori Keagenan.Simposium Nasional Akuntansi 9, Padang.

Scott, William r (2000).Financial accounting theory, second edition, Canada : prentice - hall Canada. Inc.

Sugiyono 2009.metodologi penelitian statistik. Universitas diponegoro. Semarang. Salemba empat.

Syafri Harahap, Sofyan. 2009. Analisis Kritis Atas Laporan Keuangan. Penerbit PT Raja Gafindo Persada, Jakarta.

Tarjo.2008. Pengaruh Konsentrasi Kepemilikan Institusional dan Leverage terhadap Manajemen Laba, Nilai Pemegang Saham sertaCost of Equity Capital.Simposium Nasional Akuntansi XI.Pontianak.

Wahyudi, Eko dan Baidori. 2008. PengaruhInsider Ownership, Collateralizable Assets, Growth In Net Assets, dan Likuiditas terhadap Kebijakan Dividen pada PerusahaanManufaktur yang Listing di Bursa Efek Indonesia Periode 2002-2006. Jurnal Aplikasi Manajemen Volume Nomor 3 Desember 2008.

Weston, J. Fred dan Thomas E. Copeland. 1996. Manajemen Keuangan. Penerbit Erlangga, Jakarta.

Zubir, Zalmi. 2011. Manajemen Portofolio. Penerbit Salemba Empat, Jakarta.

Berisi sumber-sumber yang dirujuk dalam menulis artikel. Tingkat penyerapan bahan disebut dalam sepuluh tahun terakhir. Daftar nomor referensi diharapkan 80 persen dari sumber primer yang berasal dari artikel penelitian nasional dan internasional(dalam 5 tahunterakhir). Daftar pustaka ditulis dengan mengikuti model APA STYLE. Daftar pustaka ditulis benar-benar hanya yang dimaksud dalam artikel dan disusun berdasarkan abjad.

Disarankan untuk menggunakan aplikasi Mendeley, Endnote, dan Zotero. Contoh:

(Untuk buku yang penulisnya sama dengan penerbit)

American Psychological Association. (2010). Publication manual of the American Psychological Association (6 ed.). Washington, DC: Author.

(Untuk e-book)

Bransford, J. D., Brown, A. L., \& Cocking, R. R. (2005). How people learn: Brain, mind, experience and school.from https://www.nap.edu/catalog/9853/how-people-learn-brain-mind-experience-andschool-expanded-edition.

(Untuk edited book with more than two or more editors)

Tobias, S., \& Duffy, T. M. (Eds.). (2009). Does Entrepreneurial Education Impact on Entrepreneurial Intention? New York, NY: Routledge.

(Untuk: book section/chapter in book)

Sahlberg, P. (2012). Entrepreneurial Education in University. In L. Darling-Hammond \& A. Lieberman (Eds.), Teacher education in entrepreneurial university: changing policies and practices. London: Routledge. 
(Untuk: books written by one author)

Schunk, D. H. (2012a). Learning theories in entrepreneurial education. Boston, MA: Pearson Education, Inc.

(Untuk: Translated books)

Schunk, D. H. (2012b). Entrepreneurial in an educational perspective (E. Hamdiah \& R. Fajar, Trans.). Yogyakarta: Pustaka Pelajar. (Original work published 2012).

(Untuk: books written by two authors)

Tabachnick, B. G., \& Fidell, L. S. (2007). Using multivariate statistics (Fifth ed.). Needham Heights, MA: Allyn \& Bacon.

(Untuk: online journal articles)

Van Vught, F. A. \&Westerheijden, D. F. (1994).Towards a general model of qualityassessment in higher education. HigherEducation, 28(3), 355-371. doi:10.1007/BF01383722.

(Untuk: articles written by three authors)

Teeroovengadum, V., Kamalanabhan, T. J.,\&Seebaluck, A. K. (2016). Measuringservice quality in higher education:Development of a hierarchical model(HESQUAL). Quality Assurance inEducation, 24(2), 244-258. doi:10.1108/QAE-06-2014-0028.

(Untuk: articles writtten by more than three authors)

Janssen, J., Kirschner, F., Erkens, G., Kirschner, P. A., \& Paas, F. (2010). Making the black box of collaborative learning transparent: Combining process-oriented and cognitive load approaches. Educational Psychology Review, 22(2), 139-154. doi: 10.1007/s10648-010-9131-x.

(Untuk: proceedings)

Retnowati, E. (2012, 24-27 November). Learning mathematics collaboratively or individually. Paper presented at the The 2nd International Conference of STEM in Education, Beijing Normal University, China. Retrieved from http://stem2012.bnu.edu.cn/data/short\%20paper/stem2012_88.pdf.

(Untuk: guideline/ government or organization report)

NCTM. (2000). Principles and standards for school mathematics. Reston, VA: Author.

(Untuk: legal document)

Permendiknas 2009 No. 22, Kompetensi Dasar Pendidikan Pancasila dan Kewarganegaraan Sekolah Dasar Kelas I-VI. 